\title{
Pure red cell hypoplasia secondary to isoniazid
}

\author{
C. R. Lewis and A. Manoharan \\ Department of Clinical Haematology, St. George Hospital, University of New South Wales, Kogarah, Sydney, \\ N.S.W. 2217, Australia
}

\begin{abstract}
Summary: We describe a 77 year old man who developed pure red cell aplasia while receiving antituberculous therapy including isoniazid. Prompt recovery occurred following cessation of isoniazid. In this paper we also review previously described case reports of isoniazid-induced pure red cell aplasia.
\end{abstract}

\section{Introduction}

Pure red cell aplasia (PRCA) is characterized by a selective reduction or elimination of the erythropoietic cell line in bone marrow; ${ }^{1}$ both granulocytic and megakaryocytic production remain normal. Acquired cases of PRCA are often secondary to drug exposure and have been reported in association with dilantin, chlorpropamide, tolbutamide, phenylbutazone, penicillin, cotrimoxazole and isoniazid..$^{1-7}$ Five cases of isoniazid-induced PRCA have previously been reported in the English literature ${ }^{6,7}$ In this article we report one additional case, and review the literature.

\section{Case history}

A 77 year old man with a past history of pulmonary tuberculosis diagnosed in 1940, was admitted in September 1983 with a one month history of malaise, weight loss and dyspnoea. A chest X-ray revealed a left pleural effusion. Mycobacterium tuberculosis was subsequently cultured in both sputum and pleural fluid and he was commenced on combination chemotherapy of isoniazid, rifampicin, ethambutol and pyridoxine. At this time the full blood count was normal: haemoglobin $13.3 \mathrm{~g} / \mathrm{dl}$, white cell count $5.7 \times 10^{9} / 1$ (normal differential), platelets $256 \times 10^{9} / 1$. Rifampicin was stopped one month later due to anorexia and nausea and streptomycin substituted:

In January 1984 he was re-admitted with an 8-week history of dyspnoea and fatigue. He denied any history of blood loss or jaundice. Physical examination revealed marked pallor. His liver was palpable with a span of $10 \mathrm{~cm}$; the spleen was also palpable $4 \mathrm{~cm}$ below the costal margin. At this time his only medication was the anti-tuberculous chemotherapy and this was stop-

Correspondence: A. Manoharan, M.D., F.R.A.C.P., F.R.C.P.A.

Accepted: 30 July 1986 ped on admission. Initial haematological evaluation revealed a haemoglobin of $5.0 \mathrm{~g} / \mathrm{dl}$, normocytic/normochromic film, and a reticulocyte count of $1 \%$, white cell and platelet counts were both normal at $5.3 \times 10^{9} / 1$ and $201 \times 10^{9} / 1$, respectively. All investigations for haemolysis were normal. A liver-spleen radionuclear study showed mild splenomegaly with slightly increased isotope uptake. Bone marrow aspirate performed 4 days after admission was generally hypocellular with evidence of regenerating erythroid islands. He was then transfused to a haemoglobin of $12.8 \mathrm{~g} / \mathrm{dl}$, and his anti-tuberculous medications restarted.

Two weeks later, the haemoglobin was $9.7 \mathrm{~g} / \mathrm{dl}$, with a reticulocyte count of $0.1 \%$; white cell count $5.4 \times 10^{9} / 1$, platelets $175 \times 10^{9} / 1$. A repeat bone marrow aspirate revealed hypocellularity, with greatly reduced erythropoiesis; myelopoietic and megakaryocytic cell lines were normal. This confirmed the diagnosis of pure red cell aplasia (PRCA), and ferrokinetic studies, which showed a marked reduction in plasma iron turnover and red cell utilization of iron in the presence of a normal serum iron, supported this. Isoniazid was stopped, the other anti-tuberculous drugs continued, and the patient was transfused to a haemoglobin of $12.2 \mathrm{~g} / \mathrm{dl}$. Two weeks later, the haemoglobin was stable at $12.1 \mathrm{~g} / \mathrm{dl}$, with a reticulocytosis of $5.4 \%$; white cell count $5 \times 10^{9} / 1$, platelets $188 \times 10^{9} / 1$. He has subsequently maintained a normal haemoglobin level and the reticulocyte count has returned to normal.

\section{Discussion}

The diagnosis of PRCA was made in this patient on the basis of severe and selective anaemia, reticulocytopenia and erythroid hypoplasia, the latter documented after an inadvertent re-challenge with 
Table I Previously published cases of isoniazid-induced pure red cell aplasia.

\begin{tabular}{|c|c|c|c|c|c|}
\hline & $\begin{array}{l}\text { Patient } \\
\text { Age/Sex }\end{array}$ & $\begin{array}{l}\text { Duration of exposure } \\
\text { and re-exposure (months) }\end{array}$ & Other drugs* & $\begin{array}{l}\text { Time until } \\
\text { recovery }\end{array}$ & Reference \\
\hline 1 & $32 / \mathbf{M}$ & $6.0 / 2.0$ & $\begin{array}{l}\text { PAS/Pyr } \\
\text { Insulin }\end{array}$ & 6 days & 6 \\
\hline 2 & $42 / \mathrm{M}$ & 4.5 & $\begin{array}{l}\text { Eth/Pyr } \\
\text { Phenobarbitone }\end{array}$ & 11 days & 7 \\
\hline 3 & $66 / F$ & 4.0 & Pred/Pyr & 35 days & 7 \\
\hline 4 & $53 / \mathrm{M}$ & 6.0 & Pyr & 30 days & 7 \\
\hline 5 & $81 / \mathbf{M}$ & 2.0 & Eth/Pyr & 4 days & 7 \\
\hline 6 & $77 / \mathrm{M}$ & $3.0 / 2$ weeks & Eth/Strep/Pyr & $\begin{array}{l}4 \text { days (marrow) } \\
/ 14 \text { days (peripheral blood) }\end{array}$ & This report \\
\hline
\end{tabular}

isoniazid; his initial bone marrow examination performed 4 days after cessation of isoniazid showed early erythroid regeneration.

The duration of exposure to isoniazid before presentation with anaemia ranged from 2 to 6 months in the cases reviewed (Table I). However, in our patient this period was only 2 weeks after the re-administration of the drug; this was confirmed on both the bone marrow aspiration and the reticulocytopenia. This shortened time interval was also noted in Patient 1 (Table I) after his re-exposure to isoniazid. This rapid development of the PRCA may represent increased susceptibility to the toxic agent after re-exposure, or more likely, that the isoniazid-induced PRCA may be generally rapid in onset but is not recognized until the patient becomes symptomatic of his anaemia.

The length of time elapsed following the cessation of the isoniazid until the onset of initial erythroid regeneration varied from 4 days to 35 days. Certainly, in our patient there was evidence of early recovery in the form of erythroid 'islands' on the initial bone

\section{References}

1. Krantz, S.B. Pure red cell aplasia. N Engl J Med 1974, 291: $345-350$.

2. Jeong, Y.G., Young, Y.\& River, G.L. Pure red blood cell aplasia and diphenylhydantoin. JAMA 1974, 229: 314315.

3. Recker, R.R. \& Hynes, H.E. Pure red cell aplasia associated with chlorpropamide therapy. Arch Intern Med 1969, 123: 445-447.

4. Swineford, O., Curry, J.C. \& Cumbia, J.W. Phenylbutazone toxicity: depression of erythropoiesis. Arthritis Rheum 1958, 1: 174-177.

5. Stephens, M.E.M. Transient erythroid hypoplasia in a marrow aspirate performed 4 days after ceasing thes isoniazid. This rapid recovery was responsible for thet early confusion in the diagnosis, and the re-commen $-\infty$ cement of the isoniazid. This recovery rate is consis -0 tent with the relatively short half-life of isoniazid, ino which $75 \%$ to $95 \%$ of the drug is excreted within 24 hours, ${ }^{8}$ except in patients with the 'slow acetylator' phenotype.

Isoniazid has been associated with other red cell dyscrasias such as sideroblastic anaemia, megalobloss $-\infty$ tosis and auto-immune haemolytic anaemia.' T通e incidence of isoniazid-induced PRCA is not know but with only two previous reports in English langu publications it is probably rare. The pathogenesis of PRCA is also not known; suggested mechanisms include a direct toxic effect of isoniazid, or its metabolite, on the erythroid precursor cells, or forma $\rightarrow$ tion of a drug-antibody complex. ${ }^{7}$ Whatever the mechanism, the prompt recovery observed in this and the previously reported cases, ${ }^{6,7}$ suggest that it is readily reversible toxicity, provided it is recognized. patient on long term co-trimoxazole therapy. Postgrad
Med J 1974, 50: 235-237.

6. Goodman, S.B., Block, M.H. A case of red cell aplasia긍 occurring as a result of anti-tuberculous therapy. Blood 1964, 24: 616-623.

7. Hoffman, R., McPhedran, P., Benz, E.J. \& Duffy, T.P.N Isoniazid-induced pure red cell aplasia. $\mathrm{Am} \mathrm{J} \mathrm{Med} \mathrm{Sci}{ }^{\circ}$ 1983, 286: 2-9.

8. Des Prez, R. \& Boone, I.U. Metabolism of $\mathrm{C}^{14}$ isoniazid inN్ humans. Am Rev Respir Dis 1961, 84: 42-51.

9. Addington, W.W. The treatment of pulmonary tuberculosis. Arch Intern Med 1979, 139: 1391-1395. 